\title{
分子シミュレーションを用いたアスピリンの結晶成長メカニズムの予測
}

\author{
畑中俊亮, ${ }^{a}$ 吉橋泰生, ${ }^{b}$ 伊藤雅隆, ${ }^{b}$ 寺田勝英, ${ }^{c}$ 米持悦生 ${ }^{*, d}$
}

\section{Prediction of the Crystal Growth Mechanism of Aspirin Using Molecular Simulations}

\author{
Toshiaki Hatanaka, ${ }^{a}$ Yasuo Yoshihashi, ${ }^{b}$ Masataka Ito, ${ }^{b}$ Katsuhide Terada,${ }^{c}$ and Etsuo Yonemochi ${ }^{*, d}$ \\ ${ }^{a}$ Tsumura Co. Ltd.; 3586 Yoshiwara, Ami-machi, Inashiki-gun, Ibaraki 300-1192, Japan: ${ }^{b}$ Faculty of Pharmaceutical \\ Sciences, Toho University; 2-2-1 Miyama, Funabashi, Chiba 274-8510, Japan: 'Faculty of Pharmacy, Takasaki \\ University of Health and Welfare; 60 Nakaorui-machi, Takasaki, Gunma 370-0033, Japan: and ${ }^{d}$ School of \\ Pharmacy and Pharmaceutical Sciences, Hoshi University; 2-4-41 Ebara, Shinagawa-ku, Tokyo 142-8501, Japan.
}

(Received January 22, 2020; Accepted March 24, 2020)

\begin{abstract}
Controlling the physicochemical properties of a drug formulation is important for proper drug efficacy, since in the gastrointestinal tract many drugs undergo dissolution, limiting their efficacy. Factors affecting a drug's physicochemical properties include its crystal habit. Therefore, we predicted the crystal habit by molecular simulation for the purpose of controlling crystal morphology. In this study, we used aspirin as a model compound. By performing simulations based on known crystal structure data, we trained the simulation algorithm to produce the cubic and plate-like morphologies of crystals actually obtained. By these methods, we showed that the crystal plane of the crystal form actually obtained coincides with the characteristic crystal plane obtained by simulation. Furthermore, to consider the influence of the crystallization solvent on crystal growth, we simulated adsorption of solvent molecules on characteristic crystal planes. The difference in adsorption energy of the solvent molecules prevents the aspirin molecules from attaching to the crystal plane. As a result, we concluded that the crystal habit was caused by the difference in growth rate of the crystal plane. By applying the methods developed in this research, the growth of crystal planes can be predicted by molecular simulation, making it possible to efficiently obtain crystal forms with optimal physical properties for drug development. We believe that further development of this approach will lead to dramatic decreases in the cost and duration of drug development.
\end{abstract}

Key words_ - aspirin; crystal habit; crystal plane; crystal growth; adsorption energy; simulation

\section{緒言}

一般的に，経口投与された医薬品固形製剤が作用 部位で薬効を発揮するには，消化管内で医薬品有効 成分 (active pharmaceutical ingredient; API) が溶 解し, 消化管粘膜を通じて吸収される必要がある. その際，水に対して難溶性の API は溶出速度が体 内への吸収の律速となる, そのため, 難水溶性であ る API の溶出速度を把握することは医薬品を適正 に使用する上で非常に重要である.

溶出速度に影響を及ぼす原薬物性のうち, 開発初 期より頻繁に検討が行われているものに結晶多形が ある. 結晶とは, 分子が規則正しく配列してつくら

$a$ 株式会社ツムラ生産本部 CMC 開発研究所製剤研究部 製剤開発グループ, $b$ 東邦大学薬学部薬剤学教室, ${ }^{c}$ 高 崎健康福祉大学薬学部分子創剤制御学研究室, $d$ 星薬科 大学薬学部薬品物理化学研究室

*e-mail: e-yonemochi@hoshi.ac.jp
れた固体のことであるが, 同じ化学構造を持つ分子 であってもその配列が異なる結晶を有することがあ り，これを結晶多形という。多形には安定形と準安 定形が存在し, 準安定形は安定形と比較して化学ポ テンシャルが高いため, 高い溶出特性を持つ。その ため, 医薬品候補化合物の開発初期において, 結晶 多形の物理化学的な性質は極めて重要であり，それ ゆえに様々な研究が行われている. ${ }^{1-4)}$ そのほかに 溶出速度に影響を及ぼす物性に結晶形態（晶癖）が 挙げられる。晶癖は, 結晶多形と異なり，分子の配 列は同じである。しかしながら，再結晶時の晶析条 件（溶媒・温度・時間・pH），イオン強度及び不純 物の添加などの違いにより各結晶面の成長速度が変 化して, 晶癖の異なる結晶が生じ得る. ${ }^{5,6)}$

また，医薬品の製造工程中でも，原薬の純度が上 がることなどによって晶癖の異なる結晶ができ得 る、晶癖が異なれば結晶面の割合が異なり, 各結晶 面に露出する分子配列が異なるため, 物理的性質が 
異なる可能性がある，さらに，晶癖の違いは結晶全 体のぬれ性及び溶出速度に影響を及ぼすことが考え

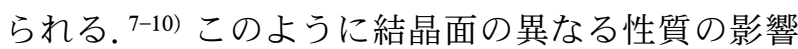
により，バルクのぬれ性及び溶出速度が異なること について，報告がなされている. ${ }^{11-13)}$ 例えば，アセ トアミノフェンは，各結晶面の水素結合の有無によ り，表面自由エネルギーが異なり，水との接触角が 異なることが報告されている. ${ }^{14)}$

溶出速度のほかにも，錠剤の製造工程では打錠時 において晶癖の違いが粉体物性に影響を及ぼすこと が報告されている. ${ }^{15)}$ 例えば，イブプロフェンは, アセトン溶液，エタノール溶液に非溶剤として水を 加えて再結晶することで棒状結晶が得られ，また， メタノール溶液を冷却して再結晶することで多面体 の結晶形態が得られる. ${ }^{5)}$ この晶癖が API の流動性 と打錠特性に影響を及ぼすことについて報告がなさ れており, 針状のイブプロフェン結晶は, 板状のイ ブプロフェン結晶よりも流動性が良好であった。 ま た，アセトアミノフェンに関しても同様に，晶癖に よって異なる流動性を示すことが報告されてい る. ${ }^{16)}$

以上の例からも，晶癖を制御及びその物理化学的 特性を評価することは，適切な薬効を示すことのみ ならず医薬品の開発及び製造工程においても，非常 に重要であることが考えられる。

特に溶出速度においては, 直接水に接触すること で API の溶出が起こるため，水へのぬれ性が悪い 医薬品の場合には晶癖が溶出速度に及ぼす影響が大 きくなると考えられる。これまで，晶癖を有するバ ルプロ酸アルギニンの結晶面に対し, 水分子の吸着 メカニズムの解明に分子シミュレーションを用いた 報告は例がある. ${ }^{17)}$ しかしながら，溶解性改善を目 的とした晶析プロセスの検討において，インシリコ による結晶形態予測の有用性に関する報告例は少な (. ${ }^{18)}$ インシリコによる結晶形態予測を発展させる ことにより，結晶の物理化学的特性が予測できるよ うになり，その後の開発プロセスにおいて優位とな り得る結晶形態を早期に把握することが可能となり, chemistry, manufacturing and control (CMC) 開発 にかかるコストと時間を大幅に削減できると考える.

これまでの研究により，アセチルサリチル酸（ア スピリン）をモデル薬物とし，晶析条件を変更する ことで異なる晶癖（立方体結晶・板状結晶）が得ら
れ，その結晶面における溶出性が API としての溶 出性に大きく影響を与えることが知られている. ${ }^{19)}$ そこで, 本研究では, アスピリンをモデル化合物と し，晶癖とそれを得るための晶析方法（本研究では 晶析溶媒に着目)，そしてインシリコによる結晶形 態予測の有用性について着目した。アスピリンの結 晶構造デー夕を用いた結晶形態予測を実施し，得ら れた晶癖の結晶面に対し，溶媒分子の吸着シミュ レーションを実施した。さらに，その吸着シミュ レーションの結果より，異なる結晶面におけるアス ピリン分子と溶媒分子の吸着エネルギーを比較し, 結晶成長メカニズムへの影響について考察した.

\section{方法}

1. 試料 アセチルサリチル酸（アスピリン； Wako Special Grade; $99.5+\%$; Wako Pure Chemical Industries Ltd., Osaka) を試料薬物として用い た.エタノール [99.5\% (w/v); guaranteed reagent; Wako Pure Chemical Industries Ltd., Osaka] と精 製水を再結晶溶媒として用いた。

2. 晶癖の異なる結晶の調製方法 アスピリン $5 \mathrm{~g}$ を $60^{\circ} \mathrm{C}$ のエタノール $100 \mathrm{~mL}$ に溶解させ， 20 $25^{\circ} \mathrm{C}$ で 24 時間静置して析出させた結晶を立方体結 晶とした。同様にアスピリン $5 \mathrm{~g}$ を $60^{\circ} \mathrm{C}$ のエ夕 ノール $100 \mathrm{~mL}$ に溶解させ，貧溶媒として $25^{\circ} \mathrm{C}$ の 精製水 $100 \mathrm{~mL}$ を 5 分間かけて加えて攪挥し， $25^{\circ} \mathrm{C}$ の恒温室で 24 時間静置して析出させた結晶を板状 結晶とした.

3. 電子顕微鏡 (scanning electron microscope; SEM）画像撮影走査電子顕微鏡（VE-7800, Keyence, Osaka）を用い，肉眼では確認できない, 粉末試料の結晶形態の違いを確認するために, SEM 画像撮影を行った。 カーボンテープを付けた ステージ上に試料を固定させ，前処理として試料に 180 秒間蒸着処理を行った。撮影電圧は $2-15 \mathrm{kV}$ に 設定し, 検出器は二次電子検出器を使用した.

4. $\mathrm{X}$ 線回折測定粉体及び単結晶面のミラー 指数付けを行うため, X 線回折測定装置 D8 DISCOVER with GUDDS (Bruker, Billerica) を用い, $\mathrm{X}$ 線回折測定を実施した。測定条件として，体陰 極は $\mathrm{Cu}-\mathrm{K} \alpha$, 検出器は Hi-STAR 2 次元 PSPC, 光 学系はグラファイトモノクロメータを用い，電圧は $40 \mathrm{kV}$ ，管電流は $40 \mathrm{~mA}$ に設定し，測定範囲 $2 \theta$ は 

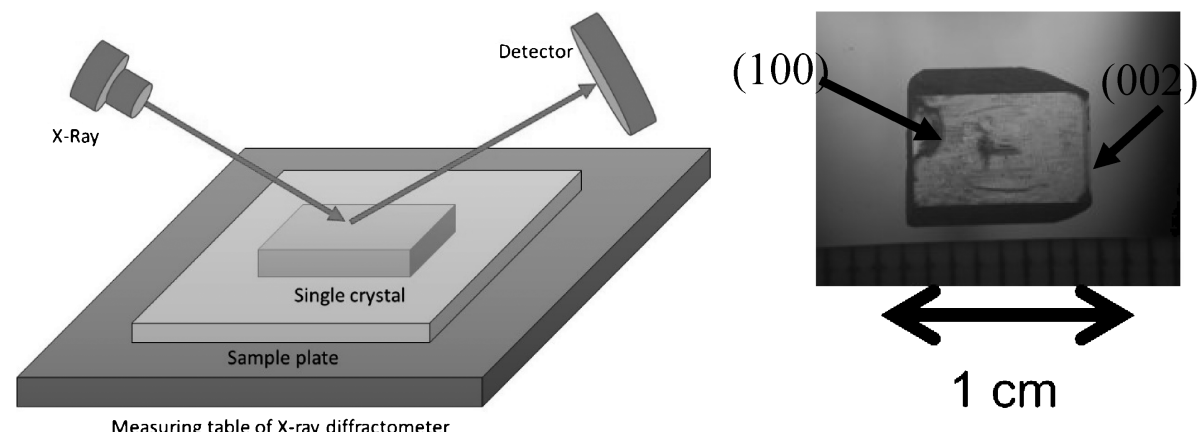

The sample plate and single crystal are parallel.

Fig. 1. X-ray Measurement Method for Single Crystal Plane and Single Plane of Aspirin

5-35゚とした.

\section{5. 単結晶を用いた結晶面の同定適切に $\mathrm{X}$} 線が結晶表面に照射されるように，得られた単結晶 の結晶面が測定プレートと平行になるよう設置し た。さらに，単結晶の高さを補正するため，装置の $\mathrm{X}$ 線照射部を $\mathrm{Z}$ 軸方向に移動及び調整し $\mathrm{X}$ 線回折 測定を実施した。得られた回折測定結果より，結晶 面の同定を実施した。なお，アスピリンの結晶面 (100)は $2 \theta=7.76$ であり，(002)は $2 \theta=15.64$ であ る.

\section{6. シミュレーションを用いた晶癖モデルの作成} ケンブリッジ結晶構造データベース（CSDSystem）よりConQuest を用いて入手した，精密化 されたアスピリンの結晶構造データを用いた（Fig. Sup. 1, CCDC Number 185472)。原子や分子のモデ リング及びシミュレーションを行うアプリケーショ ン Material Studio (ver.4.4, Dassault Systemes BIOVIA）を用い，結晶形態の予測を行った。 まずはじ めに, アスピリンの結晶構造データから, モジュー ル FORSITE を用い, 力場 COMPASS にて分子計 算を行うことで結晶構造の最適化を実施した。次 に, モジュール MORPHOLIGY, 力場 COMPASS を用いて，結晶構造予測を行った。この結晶構造の 予測にて, 各結晶面の付着エネルギー $\left(\mathrm{E}_{\mathrm{att}}\right)$ が得 られた。 さらに, 本シミュレーションソフトでは, 各結晶面の付着エネルギーから, 理論的に結晶表面 に出得る晶癖の予測が可能である。 そこで, 本研究 では，立方体結晶及び板状結晶の形態に合うよう に, モジュール MORPHOLIGY (The Growth Morphology method）にて結晶形態を変形させ晶癖モ デルを作成した.

\section{7. 各溶媒との親和性の評価及び結晶成長阻害の} 予測ここれまで, 晶析溶媒の違いにより, 板状結 晶と立方体結晶の異なる晶癖が得られることが知ら れており，それぞれの晶癖が特徵的な結晶面を有し ていることを示した，そこで，本研究では特徵的な 結晶面であった (100) 面及び(002) 面における晶析溶 媒分子の吸着シミュレーションを行った。 吸着シ ミュレーションは，モジュール SORPTIONを用い て実施した。溶媒分子の吸着対象として結晶面の最 表面にあるアスピリン分子を設定し，溶媒分子が安 定にかつ最小な吸着エネルギーとなるような分子計 算により, 結晶面への吸着エネルギーが得られる. この吸着エネルギーを用いて, 結晶面におけるアス ピリン分子と溶媒分子の親和性を評価し，そのエネ ルギーの大小から各結晶面の溶媒分子による結晶成 長阻害の予測を行つた.

\section{結 果 · 考察}

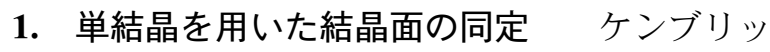
ジのデータベースより得られたアスピリン粉体の powder X-ray diffraction (PXRD) 回折パターンよ り, 単結晶の結晶面のミラー指数付けを実施した. 単結晶の X 線回折測定方法のイメージを Fig. 1 に，その XRD 結果を Fig. 2 に示す.

Figure 2 の $\mathrm{X}$ 線回折測定の結果より, 板状結晶 の単結晶は, 上面が(002)面であり, 側面が(100)面 であることが示された。この結果より，アスピリン 結晶において, 結晶面(100) 及び(002) が結晶表面に 出てくることが実験より示された.

2. 分子シミュレーションを用いた異なる晶癖モ デルの作成アスピリンの晶析方法の違いによつ 


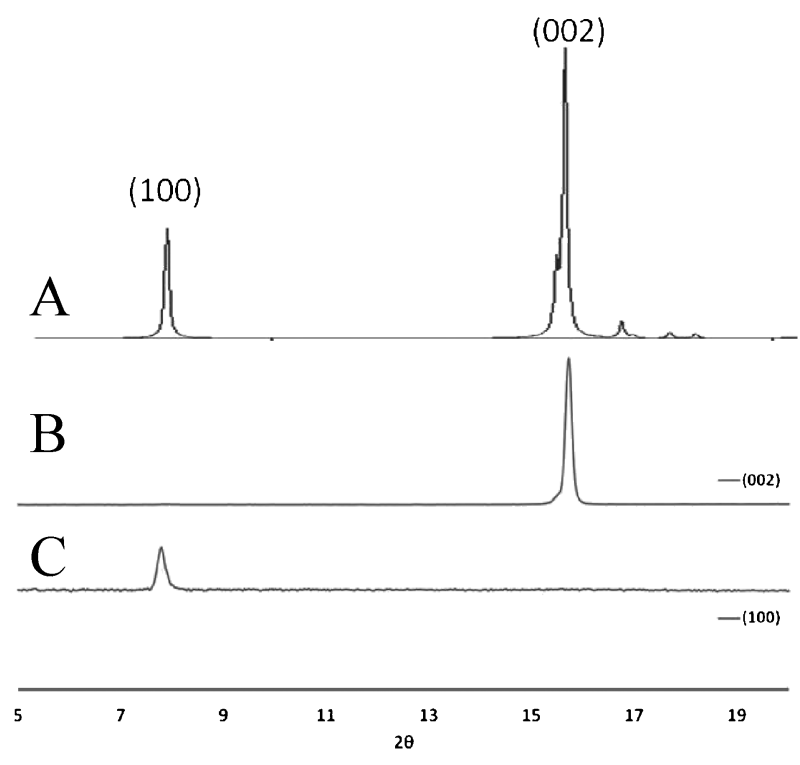

Fig. 2. XRD Pattern of Facet on the Single Crystal

A: PXRD pattern of aspirin powder, B: XRD pattern of (002) facet of aspirin single crystal, C: XRD pattern of (100) facet of aspirin single crystal.

て得られる晶癖が異なることが既に知られている. 本検討では，その異なる晶癖である立方体結晶及び 板状結晶の結晶形態を SEM 画像より確認した形状 に合うように，アスピリン分子を用いたシミュレー ションによって得られた晶癖モデルを変形させて作
成した。その結果と実際に得られている結晶の SEM 画像を Fig. 3 に示す.

SEM 画像にて確認できた結晶形態に合わせてシ ミュレーションした結果，板状結晶及び立方体結晶 のいずれも形態を一致させることができ，結晶面 (100) 及び (002)が表面に出ている点においても一致 していた。さらに，SEM 画像を用いた解析によ り，（100)面及び(002)面の結晶面の面積を概算した ところ，板状結晶の場合，(100) 面は約 $240 \mu \mathrm{m}^{2}$ で あり，(002) 面は約 $8 \mu \mathrm{m}^{2}$ であった。一方，立方体 結晶の場合，（100）面は約 $120 \mu \mathrm{m}^{2}$ であり，(002) 面 は約 $120 \mu \mathrm{m}^{2}$ であった．なお，面積計算に用いた結 晶は，SEM 画像中で結晶面を矢印にて示したもの を代表值として使用した。この結果より，板状結晶 では，(100) 面と(002) 面の結晶表面積を比較する と，(100) 面の方が約 30 倍大きくなることが示され た。一方，立方体結晶の (100) 面は，（002）面の結晶 表面積と比較して，同等であることが示された。 らに，分子シミュレーションを用いて表面積を算出 したところ，結晶の総表面積に対する結晶面の面積 割合は，(100) 面が 52.3\%であり，(002）面が 26.1\% であった。このシミュレーションの結果から，
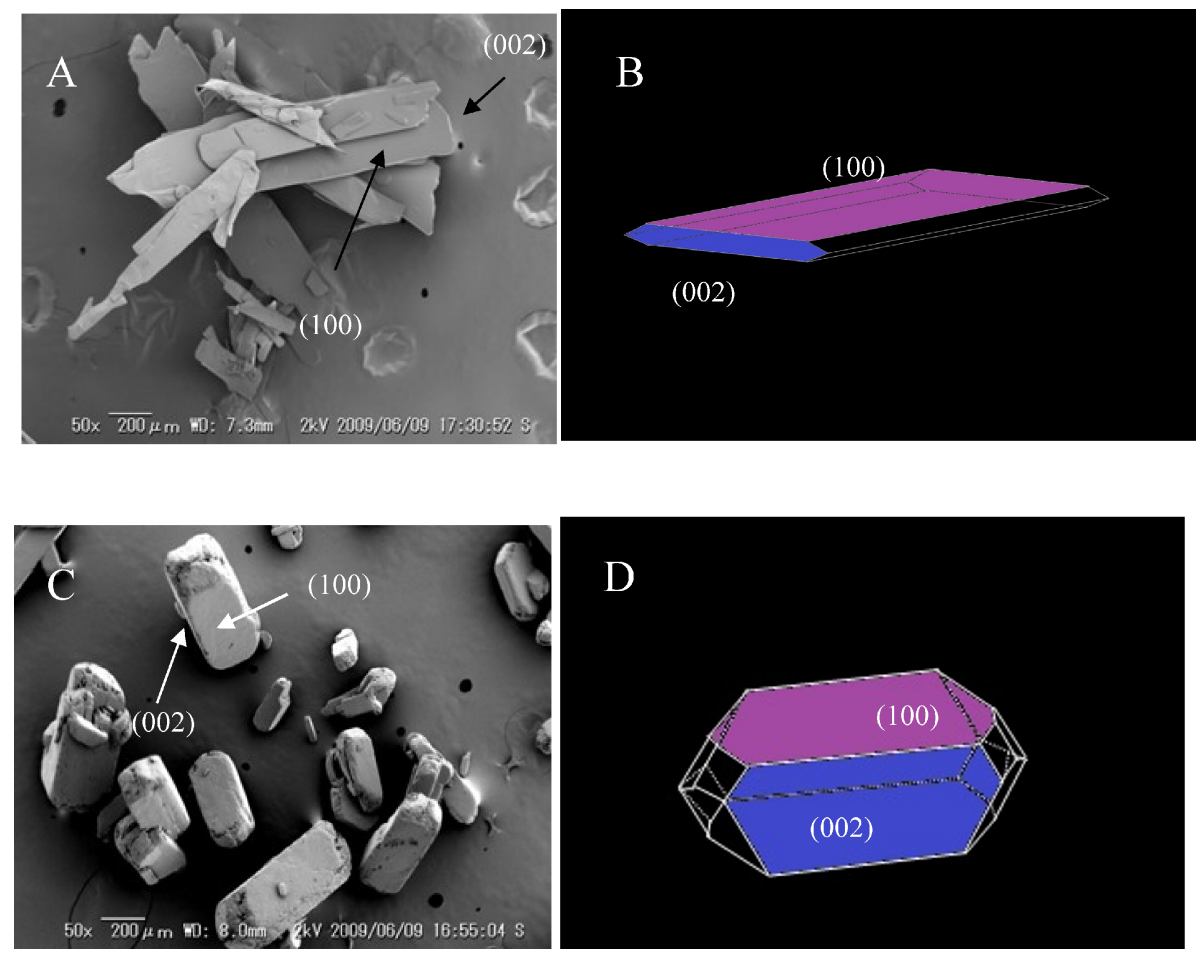

Fig. 3. Comparison of Crystal Morphology

A; Obtained plate-like crystals (SEM), B; Predicted plate-like crystal shape, C; Obtained cube-like crystals (SEM), D; Predicted cube-like crystal shape. (Color figure can be accessed in the online version.) 
Table 1. Energy of Attachment to a Crystal Facet Surface

\begin{tabular}{c|c|c|c|c|c}
\hline \hline & $(100)$ & $(002)$ & $(011)$ & $(211)$ & $(202)$ \\
\hline $\mathrm{E}_{\text {att }}(\mathrm{kJ} / \mathrm{mol})$ & 22.6 & 40.7 & 69.2 & 81.1 & 77.3 \\
\hline
\end{tabular}

（100）面と(002) 面は，他の結晶表面と比較し結晶の 表面積が大きくなると予想された。この傾向は, SEM 画像より算出した実測の表面積とも傾向が一 致していた，上記の結果より，(100)面と(002)面の 結晶成長の速度に関する優位性は他の結晶面と比較 して高いと考察した。

3. 付着エネルギー（ $\left.\mathbf{E}_{\mathrm{att}}\right)$ と結晶成長予測 異なる晶癖が生じる原因として，結晶面の結晶成 長速度が考えられる，結晶面の結晶成長とは，結晶 面に分子が付着し正しく配列していくことであり, その分子の付着する際に必要なエネルギー, すなわ ち分子の付着エネルギーが小さいほど, 結晶が付着 し易いと考える，そこで，結晶面におけるアスピリ ン分子の付着エネルギーを分子シミュレーションに より計算し, 結晶し易い面を予測した。 付着エネル ギーの結果を Table 1 に示す。また，分子が結晶面 へ付着するイメージを Fig. 4 に示す.

分子シミュレーションの結果より, アスピリン分 子の各結晶面における付着エネルギー $\left(\mathrm{E}_{\mathrm{att}}\right)$ は, (100)面及び(002)面それぞれ $22.6 \mathrm{~kJ} / \mathrm{mol}, 40.7 \mathrm{~kJ} /$ $\mathrm{mol}$ であり, それ以外の結晶面の $\mathrm{E}_{\mathrm{att}}$ は, $69.2 \mathrm{~kJ} /$ $\mathrm{mol}$ 以上の值であった。この結果より，(100) 面及 び(002)面は, 他の面の $\mathrm{E}_{\text {att }}$ と比較して小さいこと から，アスピリン分子が結晶面に吸着し易い面であ ることが示された。つまり，他の面と比較してこの 両面は, 特徴的に結晶成長し易い面であり, 異なる 晶癖が生じるメカニズムを考える上で重要な結晶面 であることが示された.

4. 溶媒との親和性の評価及び結晶成長予測 これまで, 結晶面に対するアスピリン分子の吸着 エネルギーの観点から, 結晶成長について考察して きた.ここでは, 異なる溶媒を用いて再結晶させた $2 つ の$ 結晶形態について, その溶媒がどのようにア スピリンの結晶成長に影響を及ぼすかについて検討 を行った．異なる結晶形態と晶析方法の関係は，次 の通りである，立方体結晶は，アスピリンをエ夕 ノールに溶解させ, $20-25^{\circ} \mathrm{C}$ の飽和溶液から再結晶 させた結晶であり，(100)面と(002)面方向に同じよ
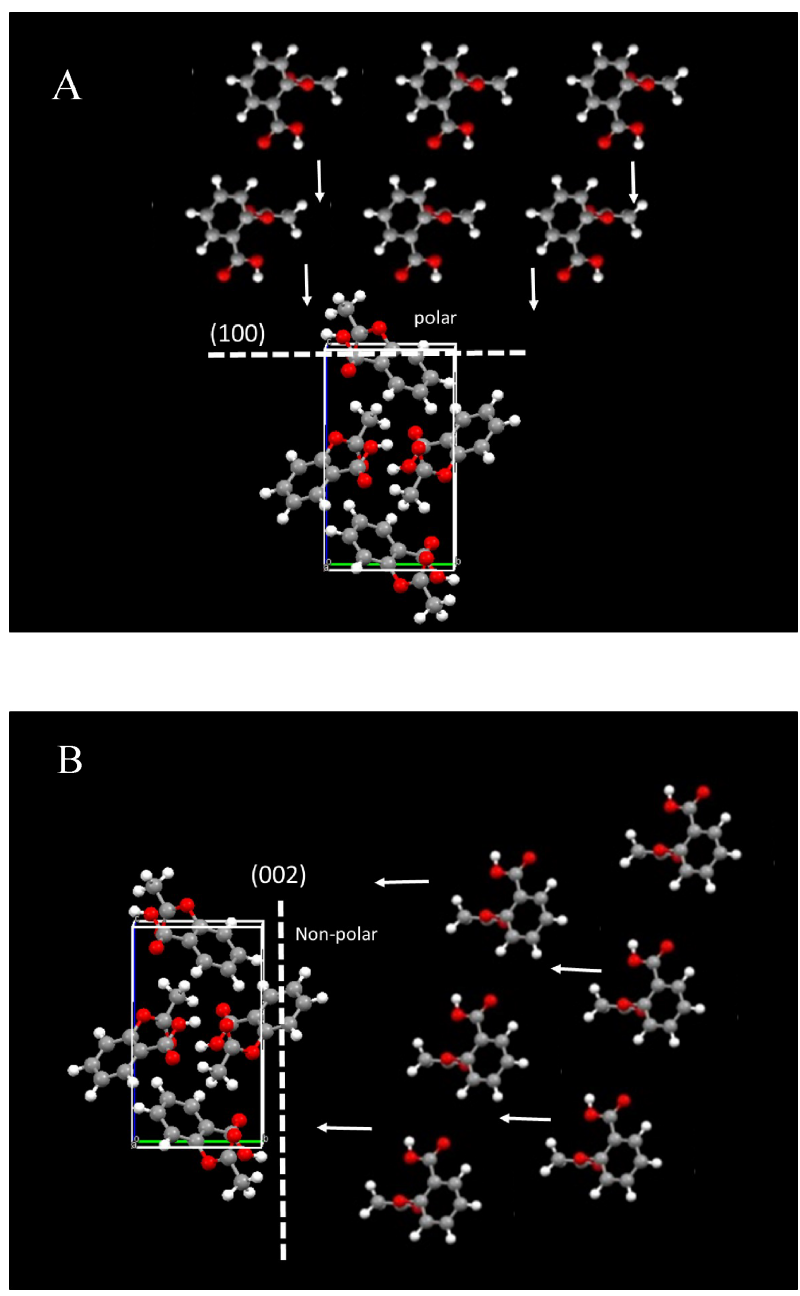

Fig. 4. Image of Molecules Attaching to a Crystal Plane A; (100) , B; (002). (Color figure can be accessed in the online version.)

うな割合で成長した形態を持つ結晶である。一方, 板状状結晶は，アスピリンをエタノールに溶解後, 貧溶媒として精製水を加えた溶液から再結晶させる ことで得られ，横長な面を持つ(100) 面と非常に薄 い結晶面である (002) 面を持つ結晶である.

われわれは，結晶面に対する溶媒分子の親和性の 大小により, 結晶面の結合部位へ溶媒分子が優先的 に吸着することで, 結晶面にアスピリン分子が付着 することができなくなり，その結果として結晶成長 が阻害され，結晶成長速度に影響を及ぼすと考え た。 そこで，再結晶溶媒の分子を用いた結晶面への 吸着シミュレーションを実施し，計算により得られ た結晶面と溶媒分子の吸着エネルギ一の大小から, 結晶面の結晶成長に対する影響を考察した。溶媒分 子の結晶面への吸着による, 結晶成長阻害のイメー ジを Fig. 5 に示す. 


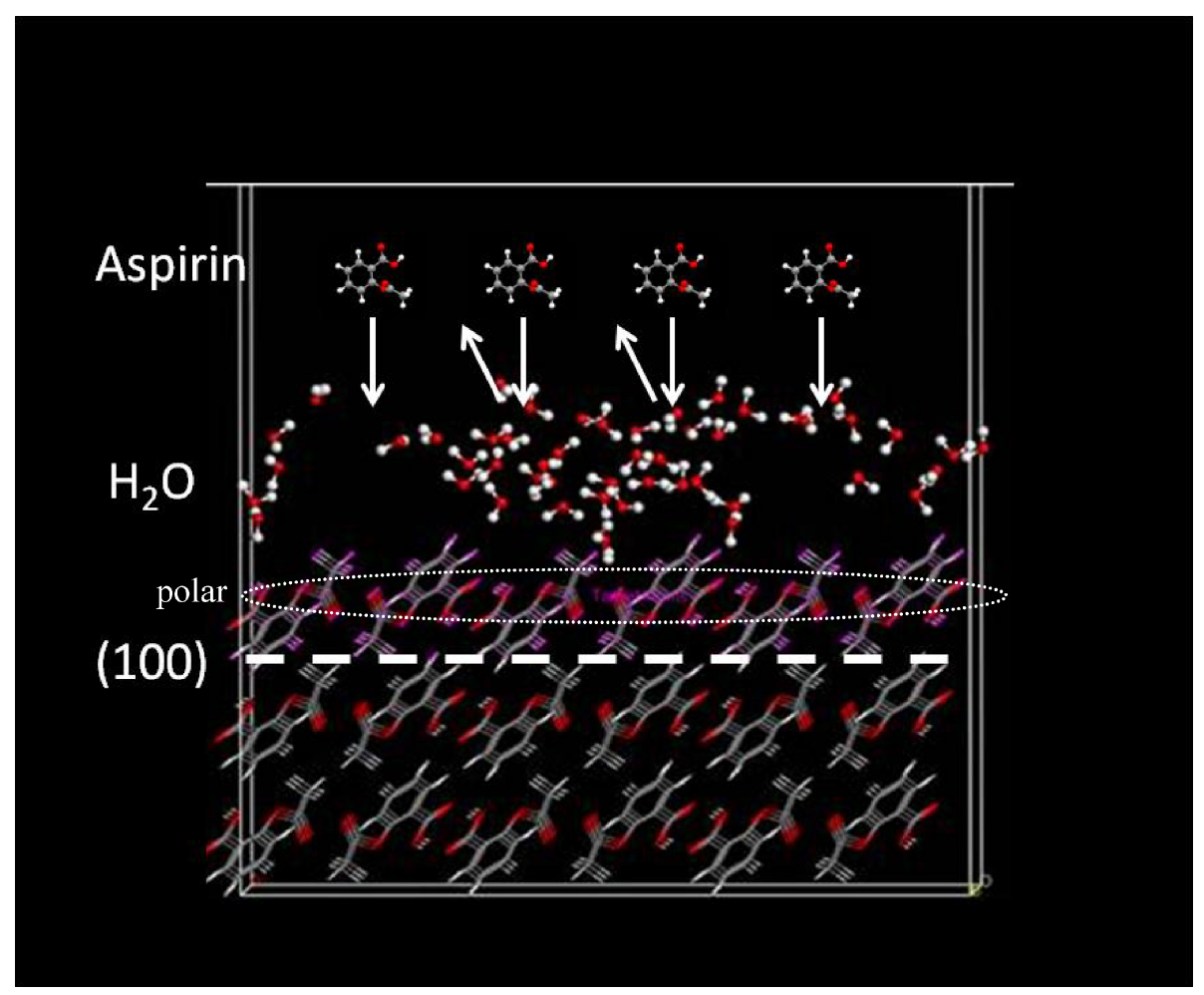

Fig. 5. Image of Adsorption of Water Molecules versus Attachment of Aspirin Molecules (Color figure can be accessed in the online version.)

まずは，立方体結晶の成長について考察するた め，(100) 面と (002) 面に対するエタノール分子の吸 着エネルギーをシミュレーションにより計算した。

吸着シミュレーションは，Fig. 6 で示したアスピ リンの結晶面における分子配列を用い，Fig. 7 で示 したように一定の大きさの箱の中で，その結晶最表 面のアスピリン分子を対象とし，50 個の溶媒分子 の結合状態と吸着エネルギーをシミュレーションに より算出することとした。 その結果を Table 2 に示 す。また，結晶面におけるアスピリン分子とエ夕 ノール分子の吸着サイトを Fig. 7 中にて矢印を用 いて示した.

アスピリン結晶面へのエタノール分子の吸着エネ ルギー（ $\left.\mathrm{E}_{\mathrm{ad}}\right)$ は，（100)面及び(002)面それぞれ，

$-748 \mathrm{~kJ} / \mathrm{mol},-723 \mathrm{~kJ} / \mathrm{mol}$ であった。この結果 より，両面に対するエタノール分子の $\mathrm{E}_{\mathrm{ad}}$ は大きな 差がないことが示された。このことから，(100)面 と (002) 面に対して同じ $\mathrm{E}_{\mathrm{ad}}$ でエタノール分子が吸 着することが考えられ，同じように結晶面の成長が 溶媒分子によって阻害される。その結果として，工 タノールから再結晶された結晶は (100) 面と (002) 面 で等方に成長し, 立方体結晶になると考えられた。
次に，貧溶媒として水分子を加え再結晶させて得 た板状結晶の成長について考察するため, 結晶面の 成長方向が特徵的である，(100) 面及び (002) 面に対 する水分子とエタノール分子の吸着シミュレーショ ン結果を比較した.

(100) 面に対する水分子とエ夕ノール分子の吸着 シミュレーションより，(100)面に対して，水分子 の $\mathrm{E}_{\mathrm{ad}}$ は $-874 \mathrm{~kJ} / \mathrm{mol}$ であり, エタノール分子の $\mathrm{E}_{\mathrm{ad}}$ はー $748 \mathrm{~kJ} / \mathrm{mol}$ であることが分かった。この 結果より，(100) 面に対する $\mathrm{E}_{\mathrm{ad}}$ は水分子の方が小 さいため, エタノール分子の吸着と比較して，水分 子の方が (100) 面へ吸着し易いことが示された。 ま た，(002）面に対する水分子とエタノール分子の吸 着シミュレーションより，(002) 面に対して，水分 子の $\mathrm{E}_{\mathrm{ad}}$ は $-841 \mathrm{~kJ} / \mathrm{mol}$ であり, エタノール分子 の $\mathrm{E}_{\mathrm{ad}}$ は $-723 \mathrm{~kJ} / \mathrm{mol}$ であることが分かった。こ の結果は，(100)面と同様に，（002）面においても $\mathrm{E}_{\mathrm{ad}}$ は水分子の方が小さいため, エタノール分子の 吸着と比較して，水分子の方が (002) 面へ吸着し易 いことが示された。

一方，(100) 面と (002) 面について水分子のみの $\mathrm{E}_{\mathrm{ad}}$ を比較すると,それぞれ $-874 \mathrm{~kJ} / \mathrm{mol},-841 \mathrm{~kJ} / \mathrm{mol}$ 

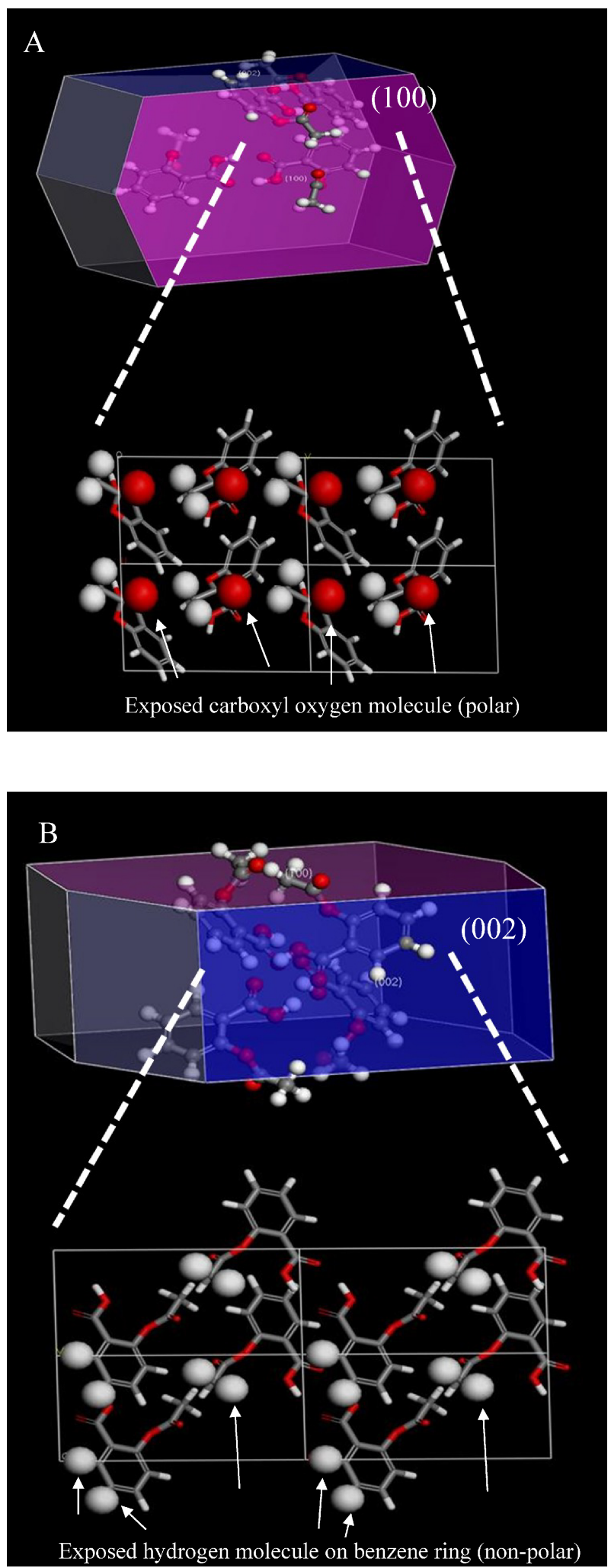

Fig. 6. Molecular Arrangement of a Crystal Plane A; (100), B; (002). (Color figure can be accessed in the online version.)
であり，各面に対する水分子の $\mathrm{E}_{\mathrm{ad}}$ に大きな差が認 められなかった.

そこで，貧溶媒を加えた後の溶媒（水とエタノー ルの混液）を想定し，（100）面と（002）面それぞれに 対する，水分子とエタノール分子の $\mathrm{E}_{\mathrm{ad}}$ の合計 ( $\left.\mathrm{E}_{\text {ad-total }}\right)$ を比較した。 その結果，(100) 面及び (002) 面への $\mathrm{E}_{\text {ad-total }}$ はそれぞれ， $-1622 \mathrm{~kJ} / \mathrm{mol}$ と - $1564 \mathrm{~kJ} / \mathrm{mol}$ であり，（100）面に対する水とエ夕 ノールの混液の吸着を想定した $\mathrm{E}_{\text {ad-total }}$ の方が小さ いことが示された。この結果より，貧溶媒として水 を加えた溶液（水とエタノールの混液）中では, (002) 面より，(100)面に対する溶媒分子の親和性が 高く，結合し易いことが分かった。 そのため, (100) 面へ溶媒分子が結合することにより (100) 面方向へ の成長が阻害されることが考えられた。つまり， (100) 面及び(002) 面へは，エタノール分子と比較し 貧溶媒として加えた水分子の方が結合し易いこと, そして，(002)面よりも (100) 面への貧溶媒を加えた 後の溶媒分子の結合の方が強いというシミュレー ション結果が得られ, 溶媒分子の結晶面への吸着に より (100) 面へのアスピリン分子の付着が阻害さ れ，その結果として (100) 面方向への成長が抑制さ れることで，板状結晶に成長したと考えられた.

結

論

立方体結晶及び板状結晶の異なる 2 つの結晶形態 について，アスピリンの結晶構造データを用いたイ ンシリコによる結晶形態を予測した。 その結果, 再 結晶にて得られた形態と同じ結晶形態にモデリング して得た特徵的な結晶面は, 実際に得られた結晶の 結晶面と一致した。この結果より，詳細な結晶形態 に関する検討を実施する前に, 結晶構造デー夕を用 いることで結晶形態を予測することができ，その特 徵的な結晶面を把握することが可能である.

また，溶媒分子を用いた結晶面への吸着シミュ レーションを実施することで得られる, 結晶面に対 する溶媒の親和性を比較することにより，溶媒が及 ぼす結晶成長の阻害度合いを予測できると考えた。

これにより，再結晶溶媒中での成長し易い結晶面を 予測することができると考えた。

以上より，本研究にて実施したインシリコによる 手法は，結晶面の成長を予測する上で有用な情報が 得られることを示した。この手法をさらに実用化に 

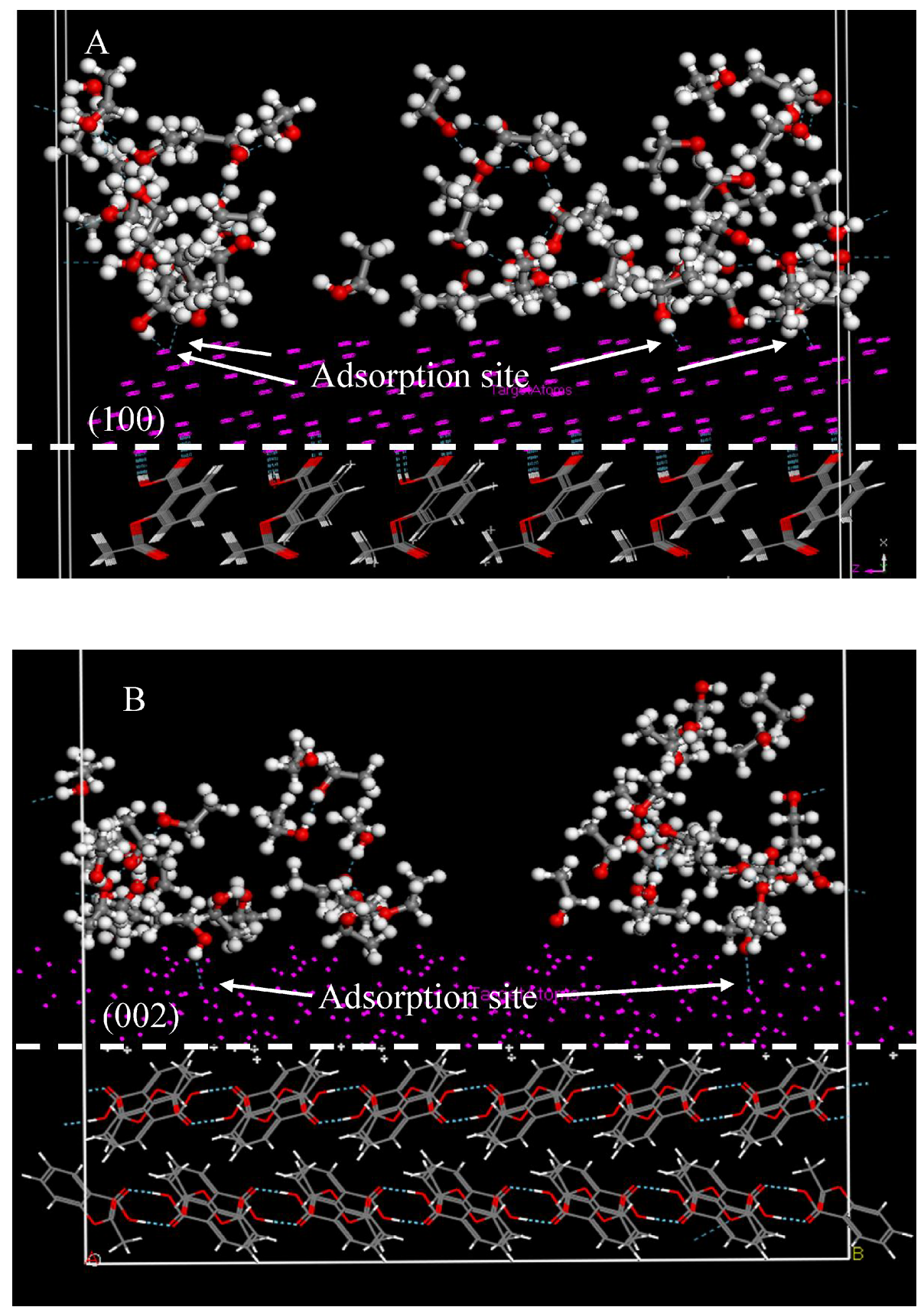

Fig. 7. Simulation of Adsorption State of Aspirin and Solvent Molecules on a Crystal Plane A; Adsorption state on (100), B; Adsorption state on (002). (Color figure can be accessed in the online version.)

Table 2. Adsorption Energies for Adsorption of a Solvent to a Crystal Surface $(\mathrm{kJ} / \mathrm{mol})$

\begin{tabular}{c|c|c|c}
\hline \hline Adsorption energy $(\mathrm{kJ} / \mathrm{mol})$ & Ethanol & $\mathrm{H}_{2} \mathrm{O}$ & Total \\
\hline$(100)$ & -748 & -874 & -1622 \\
\hline$(002)$ & -723 & -841 & -1564 \\
\hline
\end{tabular}

向け発展させることで，医薬品の CMC 開発初期段 階において，物理化学的に優位な結晶面を選択的に 成長させる等の晶析制御が可能となることから，医 薬品開発におけるコスト削減と大幅な時間削減が期 待できる.さらには, API の物理化学的性質の改 善により，効率的な体内への吸収やそれに伴う API 配合量減など，多くの製剂化開発におけるメ リットがあると考える. 
利益相反畑中俊亮（株式会社ツムラ社員）, 吉橋泰生（開示すべき利益相反はない），伊藤雅隆 (開示すべき利益相反はない), 寺田勝英（開示すべ き利益相反はない)，米持悦生（開示すべき利益相 反はない)。

\section{Supplementary materials この論文のオンライ} ンに Supplementary materials（電子付録）を含ん でいる.

\section{REFERENCES}

1) Wei Y., Ling Y., Su M., Qin L., Zhang J., Gao Y., Qian S., Chem. Pharm. Bull., 66, 1114-1121 (2018).

2) Mudalip S. K. A., Bakar M. R. A., Jamal P., Adam F., Man R. C., Sulaiman S. Z., Arshad Z. I. M., Shaarani S. M., MATEC Web Confer, 150, 02004 (2018).

3) Du D., Ren G.-B., Qi M.-H., Li Z., Xu X.-Y., Crystals, 9, 161 (2019).

4) Nicoud L., Licordari O. F., Myerson A. S., Cryst. Grow. Des., 18, 7228-7237 (2018).

5) Nguyen T. T. H., Rosbottom I., Marziano I., Hammond R. B., Roberts K. J., Cryst. Grow. Des., 17, 3088-3099 (2017).

6) Wang X. Q., Xu D., Chow Y. T., Zhang G. H., Lü M. K., Yuan D. R., Chan H. P., Sun H. Q., Geng Y. L., Chow C. K., Ren Q., Chu P. L., J. Cryst. Grow., 267, 263-269 (2004).

7) Panchagnula R., Sundaramurthy P., Pillai O., Agrawal S., Raj Y. A., J. Pharm. Sci., 93,
1019-1029 (2004).

8) Modi S. R., Dantuluri K. R., Perumalla S. R., Sun C. C., Bansal A. K., Cryst. Grow. Des., 14, 5283-5292 (2014).

9) Bukovec P., Benkič P., Smrkolj M., Vrečzer F., Pharmazie, 71, 263-268 (2016).

10) Di Martino P., Beccerica M., Joiris E., Palmieri G. F., Gayot A., Martelli S., J. Cryst. Grow., 243, 345-355 (2002).

11) Šimek M., Grünwaldová V., Kratochvíl B., KONA Powder Part. J., 34, 197-206 (2017) .

12) Prasad K. V., Ristic R. I., Sheen D. B., Sherwood J. N., Int. J. Pharm., 238, 29-41 (2002).

13) Nokhodchi A., Bolourtchian N., Dinarvand R., Int. J. Pharm., 250, 85-97 (2003).

14) Chow A. H. L., Hsia C. K., Gordon J. D., Young J. W. M., Vargh-Butler E. I., Int. J. Pharm., 126, 21-28 (1995).

15) Heng J. Y. Y., Bismarck A., Lee A. F., Wilson K., Williams D. R., Langmuir, 22, 27602769 (2006).

16) Rasenack N., Müller B. W., Int. J. Pharm., 244, 45-57 (2002).

17) Ito M., Nambu K., Sakon A., Uekusa H., Yonemochi E., Noguchi S., Terada K., J. Pharm. Sci., 106, 859-865 (2017).

18) Yonemochi E., Farumashia, 52, 407-411 (2016) .

19) Yonemochi E., Bunri Gijyutsu, 41 (1) , 16-20 (2011). 